\title{
AMENDING THE WAGNER ACT: THE PROBLEM FROM THE.MANUFACTURER'S VIEWPOINT
}

\author{
John C. Gali* and Raymond S. Smethurst $\dagger$
}

Few people would deny that something is vitally wrong with a system of industrial law or lawlessness which wrought such economic havoc as this nation witnessed in 1937..$^{-1}$ Persons philosophically inclined might condone it as a temporary and passing phenomenon of a revitalized labor movement. Employers who have suffered more directly, if not more seriously than the public generally, however, cannot be expected to view the ruins with such equanimity. To them, the impossible situation of the past year is the inevitable result of a new and extreme form of government intervention in the field of labor disputes.

Some may say in reply that recent changes are the inevitable result of union suppression and of "government by injunction." Nevertheless, most employers in manufacturing enterprise derive no solace from the assurance that the waywardness of a few has caused their present plight. For our purposes, however, even if we admitted that employers generally were crusaders against unionism or that the use of injunctions was uniformly abused and perverted, it is evident that no democracy can justify perpetration of another wrong, even more injurious to its constituent people, on the theory that two wrongs make a right. Even a casual examination of the present policy of government intervention will readily disclose the extreme to which the pendulum has now swung.

- LL.B., I922, George Washington University. Member of the District of Columbia and Virginia Bars. Counsel, National Association of Manufacturers; counsel for various manufacturers' and employers' associations. Author of Some Observations on British Experience in the Field of Employment Relations and Social Insurance; contributor to various publications on labor legislation, social security, and other subjects of federal legislation.

† B.S., Harvard University; LL.B., George Washington University. Member of the District of Columbia Bar. Associate Counsel, National Association of Manufacturers. Contributor to legal periodicals.

While the amendments herein recommended have been approved by the National Association of Manufacturers, in many respects the detailed interpretation of such amendments represents the views of the writers only.

${ }^{1}$ According to statistics of the U. S. Department of Labor, there were over 4,500 strikes in 1937, resulting in direct loss of employment of over 28 million man-days-more than twice the number for 1936. 46 U. S. Monthly Lazor Rev., Feb. 1938.

2 The following is a partial list of activities which an employer now utilizes at his peril regardless of the legal or illegal conduct of employees or their organizers. Use of such practices may give rise to a proceeding under the National Labor Relations Act of possibly an investigation by the Senate Civil Liberties Committec: Refusal to hire union men; conditioning employment on retention of non-union status; discrimination against union employees in layof, discharge or re-employment; use of lockout to anticipate strikes; use of blacklist as corollary to union boycott; protection of workers or property by use 
Now that the Supreme Court has sustained the Norris-La Guardia Act and the National Labor Relations Act, many employers feel that the chief responsibility for alleviating the present situation rests with the Congress of the United States. Some believe that amendment of the National Labor Relations Act alone would be the most effective method for restoring some semblance of balance in the role government should play in the field of labor disputes. Others believe that such amendments would constitute only a beginning or at best a partial solution to the problem, and much can be said for the argument that we need a complete revision of our present labor policy, embracing reconsideration of anti-injunction laws, the policy and provisions of the National Labor Relations Act, the elevation of conciliation and mediation facilities to a more important position as a means of dealing with labor disputes, and possibly adoption of machinery for compulsory investigation in cases of extreme need. Obviously this broader problem cannot be explored here. Our purpose now is simply to discuss amendments proposed by those we represent as a means of correcting an unequal law which has likewise failed to promote industrial peace.

In approaching these amendments to the National Labor Relations Act our position should be made clear. We are not suggesting an era of unrestricted warfare or that employers be licensed to use any devices they see fit to combat strikes or the organization efforts of labor. The major purpose of amendments we support is to discourage the more objectionable union abuses as they more directly affect employers and the public, and for convenience we classify these in the following categories:

(I) Practices directly harmful to the public, such as general and sympathetic strikes; jurisdictional disputes and disputes occasioned by the split in the ranks of organized labor; collusive agreements between unions and employers; and excessive contributions to political parties and candidates.

(2) Practices primarily harmful to employers, such as seizure of plants during sitdown strikes; calling of strikes without notice; violations of collective bargaining agreements; violence, mass picketing of plants, sabotage and the destruction of property.

(3) Practices primarily harmful to the members of the unions themselves, such as misuse of union funds; padding of rolls; perpetuation of union officials; excessive

of detectives or armed guards; filling place of strikers or encouraging so-called back-to-work movements; appeals to civic organizations, local public officials or the community for support in resisting arbitrary demands or for protection in resuming operations; refusal to recognize or deal with any labor organization; expressing criticism against unions; membership in employer organizations; and removal of plant to another locality.

While the employer has been shackled, no restraints whatever have been imposed on unions. At the same time, equitable relief to restrain unlawful activities during strikes has been made almost impossible to obtain by federal and state anti-injunction laws.

The above practices are cited not to indicate approval but simply to portray how completely employers may be at the mercy of unserupulous unions and their organizers. While the list indicates how completely the law protects employees in their freedom of association, it likewise shows the current tendency of restricting the equal freedom of association on the part of employers and of enforcing isolation upon individual employers in dealing with labor combinations. 
dues, assessments, fines and penalties; failure to permit auditing of union accounts; failure to hold meetings or to consider member grievances; etc.

While all of these practices would merit careful scrutiny and appraisal in the formulation of a national labor policy, we believe that industry, in suggesting legislative correction of union abuses, should keep clearly in mind the point made by the Supreme Court in the recent Virginian Railway case, namely, that: "The railroad can complain only of the infringement of its own constitutional immunity, not that of its employees." 3

The employer is not in contemplation of law guardian of the rights of employees nor of union members, and sound policy would dictate that in suggesting legislative reforms industry and employers generally should confine their suggestions to practices which operate primarily against their own interest and that of the general public. Therefore we do not now advocate government control of the purely internal affairs of labor organizations, whether it be accomplished through the National Labor Relations Act or through some other legislative medium.

The immediate and ultimate purpose of our suggested amendments to the $\mathrm{Na}$ tional Labor Relations Act is to achieve a higher degree of self-restraint and responsibility on the part of labor organizations for the protection of employers and the public. That purpose must be frankly acknowledged. At the very beginning, however, it should be made clear that the remedy proposed is not the compulsory incorporation of labor unions. While this has often been urged as the best method of securing responsibility and more effective liability both to union membership and to employers, we are definitely opposed to any legislation designed to compel such incorporation. Incorporation would not guarantee financial ability to meet legal obligations or judgments rendered against unions, any more than it now guarantees the same result on the part of ordinary business corporations. Neither would incorporation give any assurance that contracts would be performed, any more than we have such assurance in the case of unincorporated labor organizations. Nor would incorporation insure any higher quality of leadership for labor organizations. A labor leader who can secure his continued election and position of dominance in an unincorporated labor union could continue to do so in an incorporated one.

There are other considerations to be regarded but in our judgment, even though compulsory incorporation were constitutionally possible, it would not go far toward bringing about real "responsibility" on the part of labor organizations. On the contrary, it is at best an incidental step toward that result.

\section{Proposed Amendments to the National Labor Relations Act}

The organization with which we are identified has approved and suggested the following amendments to the National Labor Relations Act:4

\footnotetext{
2 Virginia Railway Co. v. System Federation No. 40, 300 U. S. 515 (1937).

"See "Employment Relations," approved by the National Association of Manufacturers, Dec. 1937, reprinted I LABOR REL. REP., 383 (1937).
} 
"(I) The function of government, as declared by President Roosevelt in settling the automobile strike in March, 1934, should be only that of assuring that employees shall not be subject to coercion from any source. The National Labor Relations Act and similar state acts should be amended accordingly.

"(2) The National Labor Relations Act, and similar state acts, should be amended so that no employer could be penalized for failure to deal with any labor organization, organizing, supporting, or maintaining strikes of the following character among its employees:

(a) without presentation of demands or grievances and reasonable opportunity for their consideration;

(b) in violation of employment agreements, including agreements to accept an arbitration award;

(c) to compel establishment of the check-off, or to prevent, compel or terminate the employment of any person because he is or is not a member of any organization;

(d) to prevent the use of materials, equipment or services;

(e) to compel an employer to deal collectively with supervisory officials who represent the employer himself;

(f) when accompanied by continuous and systematic acts of violence and intimidation;

(g) sit-down strikes, or other strikes which involve illegal occupation of the property of others;

(h) general strikes or strikes not in support of those in similar occupations in other plants in the same industry;

(i) to cause the commission of an illegal act or the omission of a legal duty.

"(3) The definition of 'strikers' as 'employees,' under the National Labor Relations Act, or any similar state act, should be amended to distinguish between legal and illegal strikes, persons engaging in the latter (see paragraph 2 above) not being eligible to participate in elections, to select representatives, or to be reinstated by order of the Board."

\section{"Coercion from Any Source"}

From the time the National Labor Relations. Act was before Congress in 1935 until the present, controversy has immediately developed whenever the suggestion has been advanced that the law be amended to prohibit "coercion from any source."

The chief arguments against such an amendment may be summarized as ( $\mathrm{r}$ ) objection to converting the National Labor Relations Board into a police court to hear and determine charges of physical violence or intimidation, (2) argument that such an amendment is unnecessary because physical coercion is already adequately prohibited and punished under local law, and (3) the suggestion that the National Labor Relations Act, in prohibiting interference, restraint or coercion deals only with the more subtle forms of economic coercion used by employers to defeat self-organization and collective bargaining on the part of their employees and that it would be impracticable and unwise to apply similar standards to employees or unions. ${ }^{5}$

see Sex. Rep. No. 573, Senate Committee on Education and Labor, 74th Cong., rst Sess. (1935) r6; J. Warren Madden, Address before American Federation of Labor, Oct. 5, 1937, I Labor Ret. ReP. 145 (1937); also Edwin C. Smith, Address before International Juridical Association, Jan. 15, 1938, I Lasor REL. REP. 556 (1938). The following statement in this latter address is rather remarkable, coming from 2 member of a so-called quasi-judicial body:

"If the Vandenberg amendments were passed, such a legislative perversion would have taken place on a gigantic scale. The Wagner Act which was adopted in order that unions might live would have become a means by which they might be legally done to death by their enemies. It would be far better to repeal 
The purpose of this proposed amendment is not to transform the federal government into a policeman or to have it undertake the punishment of coercive tactics employed by local organizations. In suggesting this amendment we do not propose that coercion or intimidation exerted by employees or unions should constitute an unfair labor practice or be otherwise declared unlawful within the meaning of the National Labor Relations Act. ${ }^{6}$ We.simply propose that no labor organization which is guilty of coercive tactics should be recognized under the National Labor Relations Act as an authorized and qualified representative. If the form of intimidation or coercion used should be in violation of state, municipal or other federal law then remedies under such law would still be available.

In the administration of such an amendment by the National Labor Relations Board, it would be immaterial whether state or local officials had or had not performed their police functions and duties. It would be unnecessary for the Board even to consider whether local law had been violated. Its sole function would be to receive testimony and upon a finding that a particular labor organization had engaged in activities which resulted in obtaining members or authorizations of representation by fraud, violence, intimidation or coercion, to dismiss charges brought by such a union and refuse to require the employer to deal with it as a representative of his employees. Such disqualification would constitute no death sentence. The union would still be free to use the weapons normally employed in labor disputes and by strikes and other forms of economic pressure endeavor to compel recognition and acquiescence in its demands by the employer. If a strike should result the employer would be freed from the inhibitions of the Act and permitted to utilize every legitimate weapon at his command to resist the arbitrary exercise of union power. The effect of such a finding by the Board would simply be to restore the union and the employer to conditions which existed prior to enactment of the National Labor Relations Act, so far as the duty to bargain is concerned. The government would simply refuse to direct an employer to recognize or bargain with an organization which obtained its authority to represent employees through the exercise of fraud, coercion or intimidation.

the National Labor Relations Act than to pass any such amendments. Then, at least labor would have a fighting chance," Id. at 560 .

It should be pointed out, however, that the Board has in some instances assumed police court functions and has criticized local police activities distasteful to it: See Standard Lime and Stone Company, No. C-220 (Feb. 4, 1938); Fansteel Metallurgical Corporation, No. C-235 (March 14, 1938); Washington Manufacturing Co., No. C-218 (Jan. 19, 1938); and Ford Motor Co., No. C-199 (Dec. 22, 1937). See Coercion trom any Soutce, (March, 1938) I N. A. M. LAw Digest, No. 5.

- Compare Senate Bill 2712, 75th Cong., Ist Sess. (1937) introduced by Senator Vandenberg, to amend Section 8 of the National Labor Relations Act by providing: "(b) It shall be an unfair labor practice(1) For any person to interfere with, restrain, or coerce employees in the exercise of the rights guaranteed in Section 7 , or to induce or compel or attempt to induce or compel any employee to become a member of any labor organization by means of any threat, intimidation, or coercion, or by the use of physical violence."

The Bill would likewise amend Section $\mathrm{IO}(\mathrm{c})$ of the Act and authorize the Board to "( $\mathrm{I}$ ) require reinstatement of employees with or without back pay, (2) suspend any right or privilege conferred upon auch person by this $A c t$, and (3), in the case of a labor organization, suspend or prohibit the collection or receipt of any dues, assessment, contribution, or other thing of value." 
It has been argued that such a penalty would fall with greater hardship upon individual employees who would be deprived of their right of self-organization and collective bargaining. Stated more accurately, it would mean that they would be deprived of the assistance or benefits of the National Labor Relations Act in compelling the employer to recognize and deal with their disqualified agents. While such an amendment would incorporate and require the application of principles of agency at variance with those contained in legislation such as the Norris-La Guardia Act, it is our view that no degree of responsibility can be assured without modification of those principles." Furthermore, the National Labor Relations Board itself has extended the agency principle far beyond its normal application to hold employers responsible for unauthorized acts of supervisory and other employees and even for efforts by public officials and civic organizations to restore peace and public order. It is difficult to sustain the charge of unfairness against holding the membership of a union responsible for intimidation or coercion practiced by union leaders, organizers or even individual members. The union itself has the means of correction and its membership the authority'to compel the necessary restraints upon its leaders and members.

\section{Discouraging Unlawful Strikes}

The second major amendment proposed to the National Labor Relations Act would follow the form and legal theory of the first and would permit the employer to refuse to recognize or bargain with a union found to employ strikes of the kind we have enumerated. Most of these need no elaboration.

The suggestion that employers should not be compelled by law to recognize and deal with unions which engage in wildcat strikes is but the corollary of the employer's duty under the law to bargain collectively in good faith. The practice of submitting arbitrary demands and insistence that they be met within an unreasonably short time is just as indicative of bad faith in collective bargaining as the most dilatory tactics ever utilized by employers. If the legal duty is to be placed on the employer to make every reasonable effort to reach an agreement and to enter negotiations in good faith for that purpose, then it is our contention that to some extent a similar obligation should be imposed upon the other party. The suggested amendment, however, would infict no penalty for such practices unless a strike should be called to enforce such arbitrary demands. Obviously such an amendment would still fall far short of equalizing the duty to bargain collectively in good faith. The union would still be permitted to utilize any dilatory tactics so long as it did not resort to a strike. If that occurred, the employer would be relieved of his legal duty to deal with an organization making such demands. The customary procedure of legitimate collective bargaining would provide the Board with the necessary standard for determin-

'Norris-La Guardia Act, §6: "Sec. 6. No officer or member of any association or organization, and no 2ssociation or organization participating or interested in a labor dispute, shall be held responsible or liable in any court of the United States for the unlawful acts of individual officers, members, or agents, except upon clear proof of actual participation in, or actual authorization of, such acts, or of ratification of such acts after actual knowledge thereof." 47 STAT. 70 (1932). 
ing the reasonableness of the time allowed for responding to the demands of a labor organization.

If collective agreements between labor and management are to become the accepted practire, some assurance must be given that they will be used as something more than mere campaign literature for enlisting new members. This assurance must ultimately come from labor's desire to assume collective responsibility under its contracts. It cannot be compelled by law. Let us recall, however, that the National Labor Relations Act compels the employer to make every effort to reach an agreement when requested by the bargaining representative of his employees. When the employer has met his obligations under the statute and has even gone further and entered into a contract, is it not unreasonable that the law should give no remedy whatever when a strike is called in direct contravention of the agreement?

Under the circumstances we believe it a matter of sound policy that employers be relieved from the duty of bargaining with a labor organization which, in violation of a collective agreement, and without submitting to arbitration disputes which the agreement provides shall be so submitted, engages in a strike growing out of such disputes. It should be emphasized we are not suggesting compulsory arbitration. The amendment merely contemplates that, when a union voluntarily agrees to submit disputes to arbitration, it should not be permitted thereafter to refuse to do so and endeavor to secure its demands by a strike.

The fundamental concept underlying the National Labor Relations Act is that employees should be free to join or not join any labor organization, and the law imposes adequate safeguards to protect employees from employer interference in the exercise of these rights. Furthermore the right of collective bargaining by employees upon a basis of full equality with the employer is now established and enforced by law. We believe that the freedom of employees is severely restricted when employers engage in the compulsory collection or "check-off" of union dues by deducting them from the wages of employees. Furthermore there remains no justification for the closed shop or strikes to obtain it.

Establishment of the majority rule principle in the National Labor Relations Act and the prohibition of activities on the part of employers designed to undermine or destroy an existing union eliminates the major argument for the closed-shop agreement. We do not propose however, that closed-shop agreements should be prohibited or that organizations should be denied the right to seek such agreements from employers. We do contend that strikes for the purpose of compelling acceptance of the closed shop should be discouraged. When they do occur the employer should be under no legal obligation to deal with an organization responsible for them.

One of the most serious and disturbing developments under the National Labor Relations. Act has grown from the split in the labor movement occasioned by the breach between the American Federation of Labor and the Committee for Industrial Organization. The resulting rivalry for the dominant position in the American labor movement has made a mockery of the machinery established by law to determine 
the authorized representatives of employees for collective bargaining. Certification of one union has in many instances led to strikes by the rival organization defeated in the election. In many cases these strikes have become nationwide boycotts against the products of the employer in whose plant the election was conducted. The employer may have complied with every obligation imposed under the National Labor Relations Act, and the same may be true of other employers who suffer from the spread of the boycott to other regions. ${ }^{8}$ Strikes and boycotts of this character are entirely unwarranted and should not be condoned by public authority. We believe they should be definitely discouraged and that whenever a complaint should be made against an employer for violating the National Labor Relations Act these charges should be dismissed if it appears that the union seeking recognition has engaged in strikes or boycotts of this character. We believe that the situation in the Northwest alone provides adequate justification for inclusion of this type of strike among those which must be avoided by labor organizations who seek the benefits of the National Labor Relations Act.

Strikes to compel an employer to deal collectively with organizations representing supervisory officials should likewise be discouraged. Supervisory officials with àthority to hire and fire and whose function is to convey and interpret the policies of management are in effect part of management itself. While we do not suggest that employees or officials should be deprived of the right to form or join an organization of their own choice, we do suggest that, since supervisory employees are considered as agents of management, government should not sanction union activities of the kind permitted employees generally. At this point we merely suggest that use of the strike be denied such employees. While at the present time this situation has become acute only in the field of maritime employments, there is every indication it may spread. If unions should show a growing tendency to include supervisory employees within their membership, then the remedy may be to exclude such individuals from the definition of the term "employees" in the National Labor Relations Act.

The disqualification of unions which engage in strikes characterized by systematic violence and intimidation needs no justification. We believe it a legitimate suggestion that the present policy of the National Labor Relations Act, as interpreted by the Board, under which no discouragement whatever is placed on infraction of local law, should be immediately corrected. In the same category are sit-down strikes and others which involve the illegal occupation of private property. The enforcement of local law and order should not be jeopardized or made more difficult by a federal law which places a premium upon such activities. We believe a similar attitude should be taken with respect to general strikes and strikes which are designed to compel the commission of an illegal act or the omission of a legal duty.

A sound equitable principle underlies each of the amendments thus far suggested. if a labor organization seeks to claim the benefits of the National Labor Relations

\footnotetext{
${ }^{8}$ See letter to Attorney General Cummings from Senator Steiwer of Oregon, reprinted in part in I LASOR REL. Rep., Jan. I7, 1938, P. 522.
} 
Act, that organization itself should conduct its activities within the limits of the law. When it seeks the aid of the National Labor Relations Board it is seeking equitable relief not elsewhere available in the law, and when it seeks the assistance of the Board it should come under conditions which entitle it to public aid and approval.

We realize of course that amendments of this character present certain difficulties of administration. For how long a period should disqualification persist? In what manner could a union once disqualified purge itself and thereafter be entitled to all the benefits of the National Labor Relations Act? Should disqualification comprise more than mere non-recognition of the union as a collective bargaining agent or should the employer, in addition, be permitted to disregard all of the unfair labor practices now prohibited in that law?

Inasmuch as the tendency now is to encourage collective agreements for at least a period of one year and, except in unusual cases, to certify representatives for the same period, it would appear only reasonable to fix a similar period of disqualification. With that established no real difficulty should be encountered in providing conditions under which the union may purge itself. It should be recalled that these suggested amendments do not contemplate that the employer would be given any right to petition the National Labor Relations Board and seek an investigation or any other action by the Board to have such a union disqualified. The only purpose of the amendments is to give the employer a legitimate defense in proceedings instituted by the union, and if the circumstances out of which the charges develop should likewise demonstrate that the union itself has engaged in coercive tactics or in the kind of strikes enumerated, the complaint of the union would be dismissed. Amendments so framed would not permit the use of stale claims or allow the employer to resurrect misdeeds of the union unconnected with the facts from which the union complaint emanates, or unrelated to conduct among his own employees. Nor would these amendments give the employer a free hand to indulge in forms of interference, restraint and coercion against individual employees for engaging in legitimate union activities. In each such case the employer's conduct could be justified only upon proof of the employee's misdeeds.

On the other hand we believe it absolutely essential that union members who engage in coercive methods or who participate in the strikes enumerated above, should not be ordered reinstated when discharged for such conduct or when their severance from employment was the result of their own voluntary participation in the strike. Consequently the definition of the term "employee" in the National Labor Relations Act, in so far as it includes persons whose employment has terminated as a result of a labor dispute, should be amended to exclude strikes described above. The definition should also be clarified to exclude employees who engage in coercion or intimidation of fellow workers. Employees thus excluded should be denied for 1 limited time the right to participate in elections and where they have terminated their own employment should not be eligible to compulsory reinstatement by orcer of the Board. 


\section{'Employer Petitions for Elections or Certification}

Because of the growing frequency of cases in which the employer is faced with demands from rival unions for recognition, and in which no request for an election or certification is made by either group, the suggestion has come from many sources that the Act should be amended to permit employers to petition the Board to determine which organization represents the majority. In considering this proposed amendment it should be pointed out that there is nothing in the National Labor Relations Act itself which would prevent the Board from entertaining petitions filed by employers requesting an election or certification following an investigation. In the exercise of its discretion the Board, as a matter of policy, has simply refused to entertain such petitions on the part of employers. Consequently no statutory amendment is needed to authorize the Board to proceed under Section 9 of the Act at the request of an employer caught between the conflicting claims of rival unions.

After full consideration of this form of amendment it is our belief none should be advocated at this time. It may be that the best solution might ultimately be the inclusion of another type of strike among those justifying disqualification of a union and refusal of the employer to bargain. ${ }^{9}$

\section{Miscellaneous Proposals for Amendment}

We are not unmindful of the fact that the amendments we advocate do not meet numerous and important objections to the National Labor Relations Act on the part of either employers or certain labor groups. We do not for a moment contend that acceptance of these amendments would make the law perfect. Some students of the subject feel that Section 8(5) of the law should be eliminated and that the government should not undertake to compel the recognition of unions or collective bargaining. ${ }^{10}$ While we agree with the underlying premise that bargaining must be voluntary and that labor itself in the long run will suffer most from government intervention in this particular form, we believe additional time is needed to determine the meaning and effect of the employer's duty to bargain as set forth in Section $8(5)$ of the Act. If the courts should sustain the Board's broad interpretation of this duty

\footnotetext{
${ }^{\circ}$ Such proposals presumably would include ( 1 ) mandatory investigations or elections upon request of the employer, or (2) would leave the desirability of proceeding to the discretion of the Board as is now done with respect to employee or union petitions. Mandatory action would be difficult to justify and would permit use of the Board by either party as an instrument for constant irritation and abuse. The second alternative would not correct the situation now existing for the Board could still refuse to act upon employer petitions.

The New York State Labor Relations Act permits employer petitions, but the practice has been to refuse such action unless both contesting unions consent or one union files an independent petition. See I LABOR REL. REP., Jan. 10, 1938, p. 499. The Vandenberg Bill, supra note 6, contains an additional possibilityproviding in Section 4 that: ". . . When a request has been properly made for an investigation under this section, no person shall be recognized as a representative of the employees affected until the name of such person shall have been certified as such representative by the Board."

${ }^{10}$ Latham, Federal Regulation of Collective Bargaining (1937) 6 George Washrngton L. Rev. I. The author, citing the traditional objection of organized labor, as well as the obstruction compulsory bargaining creates in establishing mediation machinery, states: “ .... Compulsory collective bargaining handicaps the development of self-reliant responsibility in labor organizations to the extent that the government stands ready to do for them what they should be able to do for themselves."
} 
we believe the time might arrive when revision or deletion of this provision may come at the demand of labor itself. ${ }^{11}$

We realize also the seriousness of the problem arising from the instability of union affiliation caused by the erratic shifting of a majority of the employees in an appropriate unit from one union to another. Nor do we ignore the problem presented by the conflicting claims of craft and industrial organizations. As with many other problems created by the novelty of the National Labor Relations Act, however, we believe most of these can be corrected by proper administration of the law itself. Such objections are in the same category as those directed against the broad administrative interpretation of Section 8 (I) of the law. Severe criticism has been raised because of the ease with which the Board has been satisfied of discriminatory action on the part of employers in hiring, laying off or discharging employees, and because of the detrimental effect of its policies on employee morale, discipline and productive efficiency. The answer to these criticisms, however, lies in the proper administration of the Act rather than in its amendment.

Serious charges have likewise been made that the Board and its examiners have not maintained a very high standard of impartiality, and that its procedure and the delay and expense involved are grossly unfair. Complaints of mal-administration have come from many sources, including labor groups, and even the courts have commented upon the absence of judicial impartiality. ${ }^{12}$ The problem of correcting the arbitrary and distorted administration of law, however, is far more difficult than the mere framing of statutory amendments.

Whether any or all of these charges of complaints are justified is a matter beyond the scope of our present discussion. The fact remains, however, that an intense feeling of distrust toward the Board does exist on a wide scale. Unless this feeling can be overcome and the Board demonstrates its impartiality, it is extremely doubtful whether any amendments adopted will bring about any material improvement. Consequently in discussing suggested amendments we must assume that the Board itself is primarily desirous of removing suspicion and of giving definite assurance that the law will be impartially and fairly administered in the future. Without the confidence of public officials, labor, employers and the public generally, the National

${ }^{21}$ See letter of William Green, Covc. Rec., Dec. 2, 1937, 75th Cong., 2d Sess., in which it is stated:

"It is now apparent that such administration by the National Labor Relations Board has repudiated generally accepted concepts and disrupted tried and tested principles of collective bargaining between capital and labor. It has impaired and destroyed rights of contract and of property upon which labor has hitherto predicated its very existence and continued progress. Such administration has brought turmoil into industrial relations, has usurped the prerogatives of the courts essential to the preservation of our democratic form of government, and has jeopardized industrial freedom and initiative-all contrary to the clear intent of the Congress to create unrestricted opportunities for labor to organize, to strengthen bargaining agencies, to promote fair practices, and to foster the objectives of a more harmonious and stabilized relationship between labor and capital as part of the national policy for the general good."

${ }^{12}$ See note $I 1$, supra. See also comments in cases of NLRB v. Remington-Rand Co., C. C. A (2nd) F́eb. 14, 1938, 2 LABOR ReL. ReP. 695; Consolidated Edison Co. v. NLRB, C. C. A. (2nd), March 14, 1938, id. 97; see (March, 1938) × N. A. M. LAw Digesr. See also Hearings before Subcommittee of Senate Committee on the Judiciary on SEN. REs. 207, 75th Cong., 3rd Sess. (1938), proposing an investigation of the National Labor Relations Board. 
Labor Relations Act, regardless of the method by which it is amended, will continue to be an instrument of strife rather than industrial peace.

We are firmly convinced that the amendments suggested would accomplish much in restoring sanity in the arena of labor disputes. Whether considered separately or in combination, they have one goal in mind. That goal is the imposition of legal restraints to go hand in hand with governmental encouragement of a strong labor movement.

In the opinion of many, labor unrest and strife in the early months of 1937 was the most important cause of our present business decline. Many believe we have experienced the normal result of conferring an unrestrained authority on private groups to organize the nation's workers.

Some of the methods used were acknowledged and described by the National Labor Relations Board itself, when it said in an early decision $:^{13}$

"Where groups are to be organized and moved into action it is not unusual for the leaders to promise more than can be secured or to indulge in some exaggeration. . . . The Act does not give to us the mandate to examine the speeches and the conduct of those whom the employees choose to follow, and to determine whether, in our opinion, they are worthy to lead. That is for the workers alone to decide. . . . In any case the fact that during a strike, necessarily a time of heated emotions, the bounds of permissible conduct may have been overstepped by men or leaders cannot be used to deny to employees their full right of representation."

President Roosevelt called attention to the situation in his annual message to Congress on January 3 , r938. He said:

"In the case of labor as in the case of capital, misrepresentation of the policy of the Government of the United States is deception which will not long deceive. In every case power and responsibility must go hand in hand."

The argument that such activities should be condoned until labor attains maturity is comparable to the suggestion that permits be given to beginners on the theory that the recipients will thereafter learn to operate a motor vehicle. There is little consolation to employers when they are told to be patient and tolerant until labor comes of age and corrects its own abuses. Laissez faire has already been discarded in the field of political action.

If labor had demonstrated any real disposition to correct its abuses in recent years, there might be some basis for expecting employers and the public to forbear and await relief on the assumption that labor itself will provide it as soon as it is fully organized. Such an expectation is contrary to both history and experience. In our humble judgment, there will be little permanent improvement in business morale or confidence unless and until government again accepts the role of impartial umpire and proclaims to all groups alike that their efforts must be conducted within the bounds of law, reason and fair play.

\footnotetext{
${ }^{2 s}$ Rabhor Co., I N.L.R.B. 470 (1936).
} 